\title{
The readiness of Latvian micro and small enterprises (MSe) for globalization
}

\author{
Iluta Riekstina ${ }^{1}$, Rosita Zvirgzdina ${ }^{2}$ and Iveta Linina $^{3}$ \\ ${ }^{1}$ Public Administration, Latvia, Turiba University; 0037129276170 \\ ${ }^{2}$ Latvia, Turiba University, 0037126408253 \\ ${ }^{3}$ Latvia, Turiba University, 0037126306922
}

\begin{abstract}
Based on the criteria set out in Annex 1 of the European Commission (EC) Regulation No.800 / 2008 and official data, about 99\% would be in the category of small and medium-sized enterprises (SMEs). In Latvia, the breakdown of economically active SMEs by the Ministry of Economics is: micro enterprises - 90\%, small enterprises - 9\%, medium enterprises $-1 \%$. The European Commission believes that it is SMEs and entrepreneurship that are key to ensuring economic growth, innovation, job creation and social inclusion in the European Union. However, globalization is one of the ways micro and small businesses can go beyond national territories to expand their business to succeed. The aim of the study is to analyze the types of activity in which micro and small enterprises in Latvia operate for 5 years and to analyze the level of potential readiness of globalization. Quantitative research is based on official business data from several sources - Enterprise Register, Ministry of Economics, Re-Identifier of the Register of Enterprises Ltd. "Lursoft", Central Statistical Bureau. The study will review data on the last 5 years by analyzing data for 2013-2017. The following research methods have been used for the research: quantitative data research approach, analytical study comparing data for five years and graphical method - visualization and analysis of visual information.
\end{abstract}

\section{Introduction}

Globalization is nothing new and its consequences have long been recognized by businesses. Globalization simply is. The consequences can be both positive and negative. Every business should think about producing and selling goods and services for consumers in different countries to regions [1]. Latvia is a small state and micro and small businesses are already at the core offers goods and services all over Latvia, so the research question is whether the companies' spheres of production are suitable for international trade, but a study by V. Chan Kim and R. Maborna of the European Institute of Business Administration (INSEAD) shows that not all companies are capable and knows how to cope with the opportunities presented by globalization[2]. Not being able to meet the needs of a much larger number of customers with the resources and expertise available [2]. Document on harnessing the opportunities of globalization [6] states that it is small businesses that need to be prepared for the challenges posed by globalization - inequality, regional labor supply, environmental 
regulations and tax policies. In a 2019 study, the authors Jeon and Degravel prove that the competitiveness of small and micro enterprises in the global market can only be achieved through innovation [16]. Innovations are also being made in specific areas of activity. At the same time, the authors point out in the study that large companies view CEOs and employees of micro and small businesses as failures as potential good employees in large corporations [17]. In 2019 Presutti and Odorici tried to explore contingent elements, such as social and business networks and accumulated entrepreneurial experience [18]. This study suggests that SMEs, which develop social networks, may enjoy considerable advantages from entrepreneurial and market orientation, improving their performance benefits. Moreover, our results show that previous entrepreneurial experience, when specific, can reinforce the impact of entrepreneurial and market orientation on firms' performance growth [18]. Therefore, it is not for nothing that $35 \%$ look at their economic potential with concern, but $53 \%$ see globalization as a threat to their country's identity [8].

The purpose of the study is to analyze the types of activities most engaged in by micro and small businesses, to understand trends and prospects for development.

The tasks of the research are:

- analyse the dynamics of the number of micro and small enterprises for five years (20132017);

- analysis of the scope of economic activities (by NACE);

- to study the financial indicators of micro and small enterprises over five years (20132017), the dynamics of financial indicators of their most frequent fields of activity.

The authors hypothesize that micro and small businesses are better able to take advantage of the opportunities offered by globalization, thereby rapidly gaining access to new markets and rapidly increasing financial performance.

\section{Methodology}

This quantitative study is based on primary data sources - official variable data for micro and small enterprises in Latvia. The study will look at data and trends for the last five years, analysing data for 2013-2017. According to Article no.5 of the Law "Law on the Annual Financial Statements and Consolidated Financial Statements", all companies are divided into micro, small, medium and large. The criteria set out in the law are different from the ones set out in Annex 1 to the European Commission (EC) Regulation No. 800/2008. The study was carried out according to the criteria set out in the Regulation for the classification of enterprises. One of the factors is the number of employees. Microenterprises include companies employing less than 10 employees and those employing small businesses employing between 11 and 49 employees. Turnover for micro-enterprises should not exceed EUR 2 million and for small businesses EUR 10 million. Balance sheet total, net turnover and average number of employees are indicators that merge merchants into a specific category - micro or small business.

The following research methods have been used for the research: quantitative data research approach, analytical study comparing data for five years and graphical method visualization and analysis of visual information. 


\section{Results and Discussion}

\section{Dynamics of the number of micro and small enterprises.}

Micro and small businesses are very important for the Latvian economy in quantitative terms. Between 2013 and 2017, these companies account for an average of 86.74\% of the total number of annual reporting companies. The calculation is based on the data analysed below.

Table 1. Annual Financial Statements (AFS) count

\begin{tabular}{|l|l|c|c|c|c|c|}
\hline No & & $\mathbf{2 0 1 3}$ & $\mathbf{2 0 1 4}$ & $\mathbf{2 0 1 5}$ & $\mathbf{2 0 1 6}$ & $\mathbf{2 0 1 7}$ \\
\hline 1. & Total number of AFS & 123846 & 128646 & 130935 & 131273 & 130256 \\
\hline 2. & $\begin{array}{l}\text { Micro, small enterprises } \\
\text { (MSE) AFS }\end{array}$ & 108401 & 112220 & 113328 & 113332 & 112117 \\
\hline 3. & \% MSE AFS from all & $87.52 \%$ & $87.23 \%$ & $86.55 \%$ & $86.33 \%$ & $86.07 \%$ \\
\hline
\end{tabular}

The study shows that significant changes are not felt even though several activities to support entrepreneurship have been undertaken at national level since 2007. The first activities were carried out during the planning period 2007-2013. The next support activities are for 2014-2020 planning period. Support activities included the following support activities: investment in the creation or reconstruction of industrial premises, training of employees to promote competitiveness, start-up of business and development of small and small enterprises in specially supported territories.

\section{Business activities (by NACE 2.0)}

To be able to assess the readiness of micro and small businesses for globalization, the authors conducted a study on how micro and small businesses operate. It is the types of business that determine what a company does, what type of business is most popular with micro and small businesses. And the analysis of modes of operation is able to demonstrate readiness for globalization, readiness to expand business. A positive aspect of increased globalization for a small business is they can often have a greater impact with their product or "message"[1]. A paving stone to globalization is the efficient connectivity of businesses and consumers worldwide by communications (internet) and shipping routes (cargo flights). Suddenly with this phenomenon, a small business not only serves their local market but are also competitors in the international arena. In keeping with this idea, small businesses have access to foreign clientele with increased globalization. Globalization has not only given massive corporations the opportunity to extend their reach and try to monopolize every market, but it has also given small businesses access to the foreign clientele who place importance on niche products that are manufactured on home soil, outside of sweatshop factories. Globalization has enabled the expansion of large corporations into countries that might have previously been off their radar. For example, the streets of urban Japan are littered with KFC and McDonald's. Coca-Cola Sold Here signs can be seen on the mountainous roads near Marrakech. These big companies are able to provide their products at a fraction of the cost meaning that to compete with them, small businesses are forced to lower their prices or face extinction.

Therefore, it is important to understand what micro and small businesses are doing, in order to understand whether the goods or services they are offering have characteristics that could be of interest to the global market. By NACE Rev. 2, the scope of all enterprises is divided into 21 top-level headings, marked by letters. Micro and small businesses operate for 19 of them. Considering that micro and small enterprises make up the majority of the total 
number of Latvian companies, it is only natural that the most popular business sector among these companies is the same as the most popular business area in Latvia.

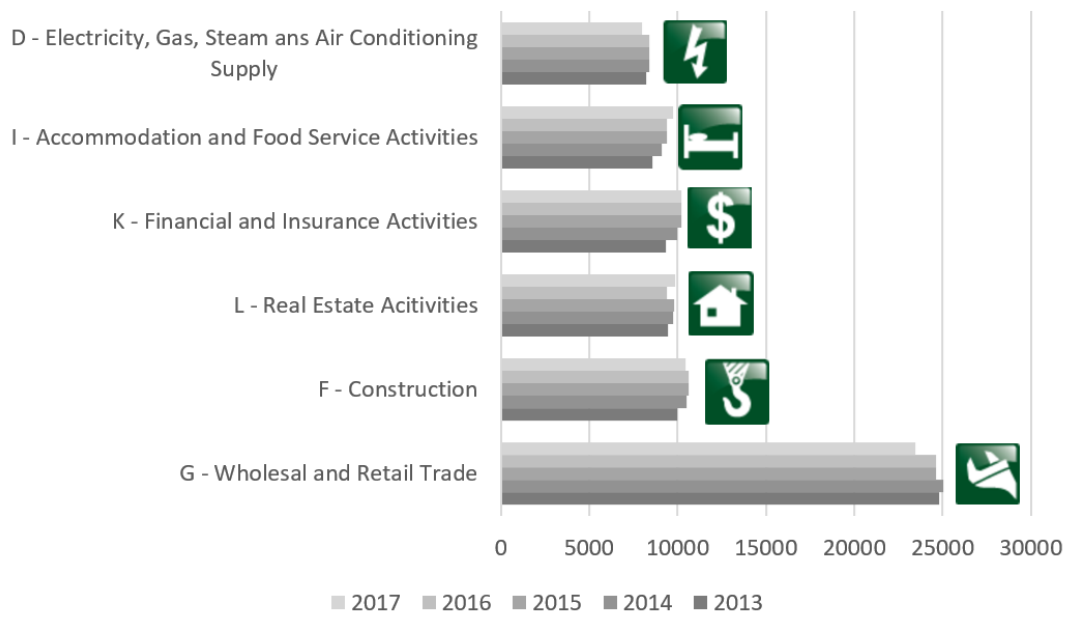

Fig. 1. TOP 6 MSe economic activities for five years

In the study, the author analysed all 19 areas of activity by NACE 2.0 classification. The data analysed show that almost one fifth or $20.9 \%$ of all micro and small enterprises in Latvia associate their core business with retail or wholesale (except cars and motorcycles). Other areas of activity are TOP 6 . Each of them operates from $7 \%$ to $9 \%$ of all micro and small businesses. TOP 6 is the second most popular field of activity - construction (10426 companies on average), followed by real estate activities (9657 companies). Among the most widespread industries in which Latvian micro and small companies are most likely to operate, accounting and legal services, accommodation and promotion services and activities in the areas of electricity, gas, heat and air conditioning are also mentioned. And this analysis of data also shows a stabilization in the scope and a slight change in their structure over the last five years. In the study, the authors analyzed 5 ways in which globalization affects micro and small businesses and their potential impact on TOP 6 business activities.

Access to The Global Market. One of the biggest impacts that globalization has had on small businesses is the fact that every business with an Internet connection now has access to the global market. Now, every consumer can reach into their pocket, pull out their smartphone, and access the products or services are trying to sell. Of all the TOP 6 activities, $\mathrm{I}, \mathrm{K}$ and $\mathrm{G}$ are most likely to have a positive impact because they are not geographically specific, as is the case with L, F, and D activities.

Remote Staffing. Another impact that globalization has had is the availability of remote staff on other parts of the world. Where it was once only an option for small businesses to have physical staff members, they can now have employees working in an office on the other side of the world. From the micro and small business sectors, the greatest positive impact can be felt in groups I, K, G they are most likely to attract remote workers.

Competition from Around the World. Next up on the list, we have competition. As globalization increases, more and more businesses enter the market. Thanks to that accessibility we mentioned earlier, this means that there's a ton more competition for small businesses around the world. For the product, you are trying to sell, there is likely going to be ten other businesses that are selling similar products. That means that businesses now need to improve the quality of their products and lower prices enough to stay competitive. Or else they risk getting kicked out of the market thanks to this high global competition. It is the 
groups D, K, F, G that are experiencing the impact of global competition as their services and goods are on the global market.

A Business Equalizer. Thanks to globalization, everything has become a bit more equal. The Internet gives every single business access to marketing tools, business information, and everything else that can make them as competitive as larger and more established companies. The business world is a lot more equal now, letting small businesses gain popularity where they wouldn't have been able to before. The groups that experience the greatest level playing field are $\mathrm{K}$ and $\mathrm{G}$.

Increase in Tourism \& Travel Companies. And lastly, a huge effect on small businesses has been the explosion of the travel \& tourism industry. More and more people are traveling the world, thanks to access to cheap travel. This also means that more businesses are entering this sector, increasing competition. There are more than 10 thousand companies in Latvia that could be positively affected by the consequences of globalization.

The first and second parts of the study show that there is no significant change in the number of years, the presentation of the accounts for the financial year or major areas of activity over a five-year period. Annex 1 to European Commission Regulation (EC) No $800 / 2008$ also sets limits on the total turnover or balance sheet total up to EUR 2 million. EUR and up to EUR 10 million. EUR. It should be noted that the breakdown of enterprises is based on financial data for the previous period. A surprising number of companies have a turnover of 0 EUR. In turn, we can divide the remaining merchants into several turnover groups. The second group, from 1 to 12,000 , is chosen because the micro-enterprise can theoretically provide a turnover of this turnover per employee approaching the national average wage. The third group has a turnover of 12001 - 50000 , the fourth group 50001 100000 , the fifth group 100000 - 2 million, the sixth group 2 million - 10 million, the seventh group more than 10 million.

Table 2. MSe Turnover Breakdown (EUR)

\begin{tabular}{|c|c|c|c|c|c|c|c|}
\hline \multirow{2}{*}{\multicolumn{8}{|c|}{$\begin{array}{l}35000- \\
30000\end{array}$}} \\
\hline \multirow{2}{*}{\multicolumn{5}{|c|}{25000}} & & & \\
\hline & & & & & & & \\
\hline \multicolumn{8}{|l|}{15000} \\
\hline \multicolumn{8}{|l|}{10000} \\
\hline \multicolumn{8}{|c|}{5000} \\
\hline \multirow[t]{2}{*}{0} & & & & & & $\square$ & \\
\hline & 0 & $1-12 K$ & $12 \mathrm{~K}-50 \mathrm{~K}$ & $50 \mathrm{~K}-100 \mathrm{~K}$ & $100 \mathrm{~K}-2 \mathrm{M}$ & $2 \mathrm{M}-10 \mathrm{M}$ & $\begin{array}{c}\text { More than } \\
10 \mathrm{M}\end{array}$ \\
\hline 2013 & 26443 & 21967 & 24744 & 9578 & 22539 & 2790 & 343 \\
\hline 2014 & 27130 & 22412 & 26505 & 9986 & 22969 & 2726 & 483 \\
\hline 2015 & 26066 & 23098 & 27757 & 10205 & 23063 & 2680 & 455 \\
\hline 2016 & 32429 & 19442 & 26663 & 9693 & 22149 & 2559 & 424 \\
\hline — 2017 & 24937 & 21917 & 27815 & 10302 & 23921 & 2735 & 486 \\
\hline
\end{tabular}

The analysis shows that in the last five years in Latvia the turnover trend of companies has stabilized. Significant increase (19.62\% compared to 2015) is observed in the number of companies with a turnover of OEUR. In 2017, however, it returns to its previous level. This is due to changes in the law on micro-taxpayers, the registration of these companies, but the inaction. Turnover analysis does not show any very significant increase in turnover by group of companies. For the past 17 years, Latvia has been developing the top of the fastest growing 
companies, aiming to select the 250 companies that show the fastest growth among micro and small businesses. According to the creators of the top [15], when evaluating the list of Latvia's fastest growing TOP 250 companies in 2016 and comparing it with the results of previous years, we can conclude that the growth rate has decreased in the last three years. Three years ago, the average (after median) turnover growth of the companies in the TOP 250 list was $455 \%$, in 2015 it was $177 \%$, but in 2016 it has decreased further and reaches 158\%. 2014-2016 Annual reports show that in 2016 the fastest growing companies in the TOP 250 list are the most represented companies in the trading sector. Almost $25 \%$ of all listed companies are active in this sector.

\section{The potential benefits and results of globalization for MSe}

What are the benefits for micro and small businesses of globalization? What are the prerequisites for the positive impact of globalization on entrepreneurship? Researchers are trying to answer these and other similar questions in the world. For example, in 2014, Saropa Mary Seila of the University of Nairobi conducted a study on the impact of globalization of Nairobi small and medium-sized enterprises [5]. And this study also concluded that small and medium-sized enterprises themselves are less aware of the positive effects of globalization, of labor and access to information, which have altered the quality and characteristics of goods produced by local firms [5]. Similar conclusions apply to Ukraine, which concludes that the results of the factor analysis revealed that in the period 2013-2015, the small business in Ukraine has not shown their ability to act as a commissary and mitigate the social consequences of the negative. trends emerging in the sector of large and mediumsized enterprises [4]. Another study was conducted in 2018 looking at the benefits for business and consumers of globalization [6]. For companies, the author emphasizes that globalization has boosted output in the Western economy:

- Globalization has enabled firms to specialize - and to increase the intensity of R\&D, innovation and capital in their output.

- Globalization has made it easier for new companies to start competing with old incumbents.

- The trade sector has increased the number of people it employs, both through exports and imports.

- Globalization has raised household income

- Globalization has spurred the spread of new technology, helping to make economies greener and more productive.

- Globalization has helped to reduce gender wage discrimination and give new opportunities to women.

- Globalization has improved the quality of management in firms and working conditions for people.

In 2018, economist Tejvan Pettinger has prepared a table with the winners and losers from globalization. And they are: 


\begin{tabular}{|c|c|}
\hline Winners & Losers \\
\hline $\begin{array}{l}\text { - Economies with low-labour cost and } \\
\text { infrastructure to export. } \\
\text { - New middle class in developing and } \\
\text { emerging economies. } \\
\text { - Exporters with competitive } \\
\text { advantage. } \\
\text { - Workers who gain jobs in export } \\
\text { industries. } \\
\text { - Educated and skilled workers who } \\
\text { have power to gain higher wages } \\
\text { Multinationals who benefit from tax } \\
\text { avoidance and outsourcing. } \\
\text { Workers who are able to move to } \\
\text { higher-income economies }\end{array}$ & $\begin{array}{l}\text { - Manufacturing sector in high } \\
\text { labour cost countries } \\
\text { - Regions e.g. 'rust belt' which have } \\
\text { seen a decline in employment. } \\
\text { - Structural unemployment amongst } \\
\text { former manual workers. } \\
\text { - Poorest } 5 \% \text { who have seen } \\
\text { stagnant incomes } \\
\text { - Environmental costs of increased } \\
\text { output, trade and growth. } \\
\text { - Land-locked countries unable to } \\
\text { develop exporting industries. } \\
\text { - Economic and social pressures } \\
\text { from migration. }\end{array}$ \\
\hline
\end{tabular}

Fig. 2. Winners and losers by Pettinger T [7].

Analyzing the existing areas of activity of Latvian micro and small enterprises, it has to be concluded that financial data do not show rapid growth in the last five years. It is possible that the opportunities provided by globalization are already being used by Latvian micro and small companies, but we will only see the results in several years.

\section{Conclusions, proposals}

1) The study does not approve the hypothesis that micro and small businesses are better able to take advantage of the opportunities offered by globalization, thereby rapidly gaining access to new markets and rapidly increasing financial performance.

2) Quantitative number of micro and small enterprises (there are about 60 thousand economically active micro and small enterprises in Latvia), financial indicators are stable and do not show significant changes / growth in the last five years.

3) In the course of the research, the author analyzed the areas of activity of the companies. As a result, the author compiled TOP 6 areas of activity for micro and small businesses in Latvia, which did not show significant changes in the last five years.

4) In the study, micro and small companies have shown stability over the last 5 years against the analyzed criteria - number dynamics and financial turnover.

5) Analyzing the scope and previous studies on the impact of globalization and these companies, the authors conclude that financial data do not show rapid growth in the last five years. It is possible that more companies are taking advantage of the opportunities offered by MSe globalization now, but we will not see the results until several years later. This is also evidenced by the fact that up to 250 companies, which is less than $0.25 \%$ of all MSe, enter the TOP of fast growing companies every year.

\section{References}

1. J. Caune, A. Dzedons, Strategiska vadisana, 71. (Lidojosa Varde, Russia, 2016).

2. W. Kim Chan, R. Mauborgne, Harvard Business Review on breakthrough thinkink, 174 (LID 2008).

3. F. Erixon, The Economic Benefits of Globalization for usiness and Consumers, ECIPE 1 (2018). 
4. S. Kalchenko, N. Trusova, D. Hrybova, \& B. Serhii, The small and large business interaction within national economy's gross added value reproduction in Ukraine. Oeconomia Copernicana 9, 3-15 (2018).

5. M.S. Seila, The impact of globalization of the leading small and medium enterprises in Nairobi county in Kenya. (University of Nairobi, 2014).

6. C. E. Passaris, The Business of Globalization and the Globalization of Business. CIM 9, 1-9 (2006).

7. T. Pettinger, Winners and losers from globalisation. ERG 10 (2018).

8. F.Timmermans, J.Katainens, Consideration document on using globalization opportunities, EK (2017). https://ec.europa.eu/commission/sites/beta-political/files/reflection-paperglobalisation_lv.pdf

9. Law on the Annual Financial Statements and Consolidated Financial Statements. Gada parskatu un konsolideto gada parskatu likums. Latvijas Vestnesis, 222 (5540), 12.11.2015. Retrieved: https://likumi.lv/ta/id/277779-gada-parskatu-un-konsolideto-gada-parskatulikums Access:12.11.2015.

10. Business Environment Review by Ministry of Economics (2015). Retrieved: https://www.em.gov.lv/lv/nozares politika/nacionala industriala politika/uznemejdarbibas _vide_. Access: 13.06.2017.

11. A description of the business incubator support program for business promotion in the regions has been specified (2018). Retrieved: http://www.liaa.gov.lv/lv/aktualitates/uznemejdarbibas-sekmesanai-regionos-precizetabiznesa-inkubatoru-atbalsta-programma. Access: 18.01.2018.

12. Business demography indicators by kind of principal activity by statistical regions (20132017). Retrieved: https://data1.csb.gov.lv/pxweb/lv/uzn/uzn_uzndarb/SBG070.px Access: data available in an online database starting with 2007.

13. Statistics Number of annual reports recorded (2019). Retrieved: https://www.lursoft.lv/lursoft_statistika/?\&id=62. Access: data available in an online database starting with 1997

14. THE FUTURE OF THE GLOBAL ECONOMY: Towards a Long Boom? (1999) https://www.oecd.org/futures/35394025.pdf

15. Fastest growing business top "Gazele" (2018). http://www.db.lv/zinas/tikai-db-visstraujakaugosie-uznemumi-470896

16. R. H.S. Jeon, D. Degravel, Open Innovation, a Tool for Globalization: The Case of South Korean SMEs. Journal of Management Policy \& Practice 20, $51-74$ (2019).

17. G.C. Banks, H.M. Woznyj, R.S.Wesslen, K.A. Frear, G. Berka, Strategic Recruitment Across Borders: An Investigation of Multinational Enterprises. Journal of Management 45, (2018).

18. M. Presutti, V. Odorici, Linking entrepreneurial and market orientation to the SME's performance growth: the moderating role of entrepreneurial experience and networks. International Entrepreneurship and Management Journal 15, 697 (2019). 